record of objective evaluation of claims both by research groups and by individual enthusiasts. Its long experience of so-called cures for muitiple sclerosis and cancer has forced it to develop a realistic scepticism for any assertions about the care of patients that are not based on trustworthy evidence. Inevitably this process will result in some new treatments being proved either useless or less valuable than had been hoped: notable examples have been anticoagulants in coronary thrombosis, ACTH and diet for multiple sclerosis, and vitamin $\mathrm{C}$ for the common cold. That is no reason for the critics to condemn the approach. New ideas have to be set up as hypotheses, tested by experiment, and revised in the light of the results. The same standards should be adopted by the opponents of orthodox medicine-and by any groups offering treatment based on alternative theories.

Relman AS. Chiropractic: recognized but unproved. N lingl f Mcd $1979 ; 301: 659-60$.

"Chiropractic in New Zealand. Report of the Commission of Inquiry. Wellington: Government Printer, 1979.

${ }^{3}$ Djerassi C. The politics of contraception. Stanford: Stanford Alumni Association, 1979.

\section{Acute renal failure after major surgery}

When acute renal failure develops after major surgery or trauma it is usually attributable to severe hypotension or hypovolaemia, or both. Many other factors may be important, however; these include hacmorrhage, loss of gastrointestinal fluids, crush injuries, anaesthetic agents, severe sepsis, and septicaemia. Early detection and correction of these "prerenal" factors is of vital importance in preventing acute ischaemic renal failure.' "In established acute ischaemic renal failure the early use of haemodialysis is equally important, ${ }^{156}$ but even with optimum care about half such patients die. Part of the explanation for this persistently high death rate is the increasing age of patients subjected to extensive operative procedures-and, indeed, the willingness of surgeons to operate despite the patient's having conditions such as heart failure, chronic respiratory failure, chronic renal disease, and impaired liver function."

Complete anuria is rare in acute ischaemic renal failure, though it may occasionally be due to acute cortical necrosis or acute glomerulonephritis. In practical terms, anuria should suggest the possibility of acute obstruction, and if it develops immediately after abdominal and particularly pelvic surgery the most likely explanation is accidental surgical ligation of both ureters or the one ureter of a single functioning kidney. On the other hand, many patients with acute ischaemic renal failure (including postoperative patients) may not even be oliguric: they may maintain a daily urine output of over a litre. The daily urine volume alone is not a safe guide to postoperative renal function."

When postoperative renal failure has been diagnosed a search must begin for its cause. One possibility that should not be overlooked is the nephrotoxic action of anaesthetic drugs such as methoxyflurane and antibiotics such as the aminoglycosides. Apart from the hazard of systemically administered antibiotics, renal damage may also be caused by the prophylactic or therapeutic irrigation of wounds, the pleural cavity, or the peritoneal cavity with solutions containing antibiotics. Davia and Siemsen" reported three patients who developed renal failure; in two orthopaedic wounds had been irrigated with a solution containing polymyxin $\mathrm{B}$, neomycin, and bacitracin; and in the third the wound had been irrigated with a neomycin solution only. All three patients also developed persistent total and bilateral hearing loss.

The absorption of antibiotics from the peritoneal cavity is better recognised as a potential cause of renal failure. ${ }^{11} 1.2$ Enthusiasm for peritoneal lavage in patients with severe peritonitis should be tempered by awareness of this hazard. Peritoneal administration of gentamicin, cephalothin, and lincomycin has been recommended in such cases, together with the parenteral administration of the same drugs in conventional doses. ${ }^{13}$ In these circumstances both renal function and serum antibiotic concentrations should be closely monitored.

Another hazard of peritoneal absorption of a nephrotoxin has been reported by Pusey et al, "whose two patients were given peritoneal lavage with a mercuric chloride solution during surgery for cancer in an attempt to exert a cytotoxic effect on any remaining viable neoplastic cells. Both patients after operation developed acute renal failure attributable to the systemic absorption of mercury, and both required repeated haemodialysis.

Blood transfusion is a potential hazard that may precipitate or contribute to acute renal failure during or after surgery. In mismatched blood transfusion, now fortunately rare, acute renal failure has generally been thought to be related to intravascular haemolysis with haemoglobinaemia and haemoglobinuria. Renal failure can, however, also follow the infusion of incompatible erythrocyte stroma, free of haemoglobin. ${ }^{15}$ In experiments on the effect of haemoglobinuria on animals other factors, such as prior dehydration or temporary renal ischaemia, have proved necessary to produce acute renal failure. ${ }^{16}$ is Infusion of haemoglobin solutions into patients results in an appreciable fall in effective renal plasma flow, urinary output, and sodium excretion in all cases; the effect on the glomerular filtration rate is variable, with a fall in twothirds of cases. "' Haemoglobinuria with or without renal failure has also been reported after the use of frozen glycerolised blood, ${ }^{21}{ }^{21}$ when it was attributed to resuspension of the red cells in outdated albumin. Traumatic rhabdomyolysis with myoglobinuria may also be a factor in postoperative or post-traumatic acute renal failure. ${ }^{2 \cdot 2}$

Renal failure after surgery can, however, only rarely be attributed to a single factor. In one recently reported series, ${ }^{2: 3}$ eight of 41 patients undergoing total hip replacement developed acute renal failure after operation. This was attributed to the use of transfusions of frozen blood, but another relevant factor was the irrigation of the orthopaedic operation sites with solutions containing neomycin, polymyxin, and bacitracin. There was suggestive evidence of intravascular haemolysis in five of the eight patients. In a further prospective group of 55 patients who received transfusions of albumin but no frozen bloed or antibiotic irrigations there was no case of acute renal failure, though the incidence of hypotension was considered to be comparable in the two groups. The type of surgery may also be important.

Whelton A, Donadio JV. Post-traumatic acute renal failure in Vietnam. A comparison with the Kurcan war experience. $f_{0}, \mathrm{hm}$ Hopkins llid $\mathrm{f}$ $1969 ; \mathbf{1 2 4}: 95-105$.

- Gillenwater JY, Westervelt $\mathrm{A}$ B. Current concepts in the pathogenesis and management of acute renal failure. 7 Lrol $1969 ; \mathbf{1 0 1}:+33-7$

"Marshall VC.. Acute renal failure in surgical patients. Br. F Surs 1971; $58: 17-21$.

' Flamenbaum W. Leslic BR. 1)iagnosis and management of renal failure in surgical pationts. (1)thep (X/in . Ninth $A m$ 1978;9:3:845-57. 
5 Evans DB. Acute renal failure. Br F Hosp Med 1978;19:597-604.

${ }^{6}$ Rainford DJ. The immediate care of acute renal failure. Anaesthesia $1977 ; 32: 277-81$

i Stott RB, Cameron JS, Ogg CS, Bewick M. Why the persistently high mortality in acute renal failure? Lancet $1972 ; 2: 75-8$.

" Anderson RJ, Linas SL, Berns AS, et al. Non-oliguric acute renal failure. $N$ Eng $\mathcal{F}$ Med 1977;296:1134-8.

'Davia JE, Siemsen AW, Anderson RW. Uraemia deafness and paralysis due to irrigating antibiotic solutions. Arch Intern Med 1970;125:135-9.

1" Bulger RJ, Bennett JV, Boen ST. Intraperitoneal administration broadspectrum antibiotics in patients with renal failure. $\mathcal{F} A M A 1965 ; 194$ : 140.

"Greenberg PA, Sanford JP. Removal and absorption of antibiotics in patients with renal failure undergoing peritoneal dialysis. Ann Intern Med 1967;66:465-79.

12 Buck AC, Cohen SL. Absorption of antibiotics during peritoneal dialysis in patients with renal failure. $\mathcal{F}$ Clin Pathol 1968;21:88-92.

13 Antibiotic lavage for peritonitis. $\mathrm{Br} M$ ed $\mathcal{f}$ 1979;2:691-2.

1 Pusey CD, Kennedy ND, Rainford DJ. Mercury nephrotoxicity from peritoneal lavage. Br $\mathcal{f}$ Surg 1979;66:200.

15 Schmidt PJ, Holland PV. Pathogenesis of the acute renal failure associated with incompatible transfusion. Lancet $1967 ; 2: 1169-72$.

${ }^{16}$ Weiner RS, Finkenstaedt JT, Rosoff CB, Jessiman AC, Walter CW. Renal function studies in the dog following the production of controlled unilateral and bilateral haemoglobinuric nephrosis. Surg Forum 1952; 2:353-61.

17 Fajers C-M. Experimental studies in hemoglobinuric nephrosis. Acta Pathol Microbiol Scand 1959;46:177-96.

1s Thiel G, Wilson DR, Arce ML, Oken DE. Glycerol induced hemoglobinuric acute renal failure in the rate II the experimental model, predisposing factors and pathophysiologic features. Nephron 1967; 4:276-97.

19 Brandt JL, Frank NR, Lichtman HC. The effects of hemoglobin solutions on renal functions in man. Blood 1951;6:1152-8.

2i) Tullis JL, Pennell RB, Melin M, et al. Problems of albumin media for deglycerolized red cell suspension. Vox Sang 1963;8:100-1.

21 Valeri CR, Henderson ME. Recent difficulties with frozen glycerolized blood. FAMA 1964;188:1125-31.

:2 Acute renal failure, hyperuricaemia, and myoglobunuria. $\mathrm{Br} \mathrm{Med} \mathfrak{f}$ $1979 ; 1: 1233-4$.

23 Gelman ML, Frazier $\mathrm{CH}$, Chandler HP. Acute renal failure after total hip replacement. F Bonc foint Surg 1979;61-A:657-60.

\section{Vancouver style}

From this issue the $B M \mathcal{F}$ is switching to the Vancouver style, a system designed to increase uniformity in scientific journals in the technical aspects of editing such as referencing. Already over 100 biomedical journals (p 23)-including all the BMA specialist journals-have agreed to use the style, and before long it could become the standard format. We hope that the problems caused by this change will be compensated by the time saved for authors and their secretaries in redrafting manuscripts from the Harvard to the numbering system when resubmitting a rejected article to another journal. Journals, too, should find that a uniform, agreed style keeps subeditorial costs to a minimum.

Originally the Vancouver group consisted only of full-time editors of biomedical journals published in English, but it has now been enlarged to include representatives of part-time editors and international journals. At future meetings it plans to discuss a code defining dual publication, increasing the use of SI units, and developing more uniform standards for abbreviations.

The second change starting in this week's $B M 7$ is the use of consecutive volume numbers, which we hope will help authors, librarians, and readers alike. As before, there will be two volumes a year, but we shall start with No 280 , so taking account of our earlier issues. To avoid any confusion, volumes of the $B M \mathcal{F}$ up to 1979 should be cited using lower case roman figures (i, ii, iii, or iv of each year) instead of arabic ones.

\section{Unsolved problems for the '80s}

If the Thames floods London this winter-and it might-will the politicians take the blame? The hazard has been plain to see since the North Sea floods of 1953, and with the peak tide level rising by a centimetre every year the risks are growing steadily. ${ }^{1}$ With luck, the much delayed barrage across the lower Thames will give London the protection it needs by 1982 , but why the delay? Why have successive Governments been so slow to act?

Politicians are conditioned to give priority to short-term problems-a fact only too familiar to doctors interested in preventive medicine. The cynical explanation is that our political leaders are interested only in projects that will give a return before the next election; the kinder alternative is that with so many demands on their time and on Government money they push into the background any questions that do not have to be answered at once. The Thames barrage is a clear example of political procrastination taking us dangerously close to the brink. The same dangerous complacency applies to many medical hazards and others of far wider concern.

One of the few, lone voices crying in this political wilderness is that of Dr John Loraine, who for the past 10 years has been preaching the dangers of global overpopulation. His latest book $^{2}$ continues that theme and also discusses three other dangers: the impending world-wide shortages of food and of energy and the proliferation of nuclear weapons. Remote as these four modern horsemen of the Apocalypse are from most doctors' day-to-day work, two of them-overpopulation and shortage of food-have close links with medicine, and on their own ground doctors are accepted as sources of informed opinion. Is Loraine right? Should more attention be focused on those threats to human survival, or is doomwatching simply a variant of science fiction?

Overpopulation is no longer a focus of public concern in the Western world. Most industrial countries have seen their birthrates decline in the 1970s as efficient contraceptives have become available and early abortion for contraceptive failure has become more widely accepted. In both Northern and Western Europe the annual rate of population increase is now $0.1 \%$ or lower. Some nations, such as France, have responded by offering financial incentives to couples to have more children; others, especially in Eastern Europe, have made their abortion laws more restrictive. Yet, as Loraine reminds us, populations are still growing in the countries of the Third World, which has $75^{\circ} \%$ of the earth's people-and where $85^{\circ}{ }_{0}$ of all births now take place. True, the world's population growth rate has probably passed its peak: in 1970 it was $2^{\circ}{ }_{0}$, but in 1978 only $1.7 \%$. Nevertheless, the momentum of growth is such that if the population became stabilised at an average of two children per family in the year 2000 total numbers would continue to grow to a plateau of 8000 million. Loraine believes that the earliest possible date for stabilisation of the family size is 2020 ; and that implies a final world population of 11000 million (in 1900 it was only 1500 million).

Surely restriction of this awesome total should be a major concern for the affluent West? Yet the developed countries transfer only $£ 250$ million a year to the Third World for family planning programmes; and world-wide, reproductive biology claims only $2^{\circ}{ }^{\circ}$ of government expenditure on research. On this issue Loraine must be right when he urges a reappraisal of priorities.

Will there be enough food for all these millions? Loraine 